\title{
The Indonesian Coup and Mass Killings, 1965-1967: A Reconceptualization of the Influence of the Cold War
}

\section{O golpe indonésio e os assassinatos em massa, 1965-1967: a recon- ceitualização da influência da Guerra Fria}

Angela Keys* e Drew Cottle**

Resumo: Este artigo explora como a situação local - política, econômica e socialmente - contribuíram para a ocorrência de dois eventos cruciais e interligados da Guerra Fria, o golpe e o massacre indonésios. O artigo demonstra como um general do exército indonésio, Suharto, foi hábil para se utilizar das narrativas da Guerra Fria como o objetivo de instigar o fervor anticomunista, o que resultou no massacre de mais de meio milhão de presumidos comunistas. Suharto foi capaz de gradualmente usurpar o poder e por fim substituir Sukarno como presidente da Indonésia. No artigo é defendida a tese de que a convergência de fatores domésticos foi decisiva para o desenrolar desses eventos que podem ser entendidos como uma Guerra Fria localizada.

Palavras-chave: Indonésia, golpe, assassinatos em massa, Sukarno, Suharto

\footnotetext{
* Teaches sociology at Charles Sturt University in Bathurst, Australia. Her research interests include sociology, politics, political economy, and Asian studies. Email: akeys@csu.edu.au ** Is senior lecturer at Western Sydney University where he teaches politics and history. He has diverse research interests which include international political economy, American, Asian and Middle Eastern politics, international communism, liberations struggles in the Third World and studies in global capitalism. Email: d.cottle@westernsydney.edu.au
} 


\begin{abstract}
This article explores how the local situation - politically, economically and socially - contributed to the occurrence in Indonesia of two crucial and interlinked Cold War events, the Indonesian coup and massacre. The article explains how an Indonesian army general, Suharto, was able to utilise Cold War narratives to instigate anti-communist fervour, which resulted in the massacre of more than half a million alleged communists. Suharto was able to gradually usurp power and eventually replace Sukarno as the president of Indonesia. It is argued that the convergence of domestic factors was critical to these events, which can be understood as a localised Cold War.
\end{abstract}

Keywords: Indonesia, coup, mass killings, Sukarno, Suharto

\title{
Introduction
}

The coup and mass killings that occurred in Indonesia between 1965 and 1966 were highly complex events. Some accounts have interpreted these events in Indonesia as orchestrated by the United States as part of the Cold War. This article presents a reconceptualisation of the coup and the massacre which contends that the context of the broader Cold War was crucial, but the local situation in Indonesia was fundamental to these occurrences. The significance of the internal dynamics of Indonesian politics, the state of the Indonesian economy, the internal divisions within the army, and the limitations of the PKI - the Indonesian Communist Party - as a political party are too often neglected in the analysis of the Indonesian massacre and coup. This article emphasises the importance of these internal dynamics in Indonesia in what can be understood as a localised Cold War in 1965 and 1966.

During the Cold War, orthodox historical accounts had neglected the significance of local factors and depicted Third World nations such as Indonesia as "little more than "pawns" or "victims" in what was then solely seen as an East-West conflict." This article aims to contribute to the body of literature that has emerged since the fall of the Soviet Union to challenge that narrow conception of the Cold War and its ramifications. While the nation of Indonesia was not a primary actor in the Cold War, the Indonesian coup and subsequent massacre were crucial incidents within the context of the Cold War. However, these incidents were shaped by domestic factors as much as they were influenced by the broader Cold War. Rather than accepting the depiction of General Suharto as a mere puppet of the United States, this article argues that local factors were influential in Suharto's seizure of power, and that he and other members of the Indonesian army utilised Cold War narratives in order to instigate both the coup and the mass killings. In analysing the events of the Indonesian coup and mass killings, this article considers both the local situation and domestic issues in addition to the influence of the Cold War. 
The Political Context prior to the Coup: Sukarno and the Cold War

Sukarno was Indonesia's first president and he ruled from 1945 until the coup resulted in his ousting in 1967. The collection of islands that today comprise the nation of Indonesia had been a Dutch colonial possession, known as the 'Netherlands East Indies', which were occupied by the Japanese during the Second World War. When the Japanese departed at the end of World War II, the Dutch attempted to recolonise the archipelago, but this was resisted and the struggle for Indonesian independence was ultimately successful. Sukarno had been a key figure in the Indonesian independence movement, and this experience shaped his foreign policy decisions as president.

Comprising an estimated 18,000 islands, it has been argued that the Indonesian archipelago is both united and divided, with its islands 'politically, economically, socially and culturally' separate. ${ }^{2}$ In a newly-independent Indonesia, Sukarno emphasised national unity, but there were challenges to this unity, such as the autonomy movements in Aceh and the Molucca Islands which had emerged by the mid-1950s. ${ }^{3}$ There were also disparities between the densely-populated island of Java and the sparsely-populated outer islands, which created a 'centre-periphery tension that has given rise to one of the most enduring perceived divisions in Indonesia'. ${ }^{4}$

Adding to the complexity of Indonesia's domestic politics, the army exerted considerable political influence. In 1957, Sukarno abandoned parliamentary democracy and introduced what he termed 'Guided Democracy,' a form of governance which placed the Cabinet and, predominantly, the president at the centre of power and national policy-making. ${ }^{5}$ Some contend that Guided Democracy was the outcome of a growing power rivalry between the president and the Indonesian army. ${ }^{6}$ Moreover, antagonism between the army and the Indonesian Communist Party, the PKI, would prove to be a critical issue in Indonesian politics. Sukarno's supremacy until the mid-1960s has been attributed largely to 'his ability to balance the army and the Communist Party against each other.' ${ }^{7}$ Nonetheless, the Indonesian army expanded its political and economic power under Sukarno's Guided Democracy. ${ }^{8}$ Provincial or local governments were brought under the authority of regional army commanders, and army generals were given senior positions in Sukarno's government, 'increasing the number of ministries under their control right up to the time of the coup.' The structured distribution of the army's power at the local or regional level throughout the archipelago was an important element in the organisation of the mass killings that would occur in 1965.

During the Cold War, President Sukarno was instrumental to the emergence of the Non-Aligned Movement. The Bandung Conference, held in April 1955, formalised an agreement between some Asian and African nations to abstain from collective defence and acts of aggression. The nations which co-sponsored the Bandung Conference were Indonesia, Burma, India, Sri Lanka 
and Pakistan. Participant countries included Saudi Arabia, Japan, Lebanon, Thailand, Afghanistan, the Philippines, Iraq, Jordan, Thailand, Nepal, Syria, Yemen, Laos, Cambodia, Vietnam, Ethiopia, Libya, Egypt, Liberia, Sudan, Turkey, Iran, and the People's Republic of China. ${ }^{10}$ The Bandung Conference was 'part of a diplomatic strategy that expressed Indonesia's position that the decolonisation processes were not yet finished." ${ }^{11}$

At issue for Sukarno was the territory of West Papua (also known as West Irian), which had remained under Dutch control after Indonesian independence was negotiated. Sukarno's determination to seize West Papua from the Dutch was central to Indonesian foreign policy during the 1950s and 1960s. ${ }^{12}$ Rather than ceding West Papua to Indonesia, the Dutch declared in 1960 that West Papua would become independent. ${ }^{13}$ Sukarno 'responded with a military build-up and a series of incursions into West Papua, backed by the threat of outright invasion.' ${ }^{14}$ Indonesia gained formal control of the territory in 1963 and renamed it 'Irian Jaya.' 15

Having succeeded in West Papua, Sukarno deployed the military to intervene in the Malay peninsula from 1963 in what is known as 'Konfrontasi.' Indonesia's foreign policy during the 1960s has been described as 'an increasingly militant policy of struggle or confrontation against imperialism, colonialism and neo-colonialism'. ${ }^{16}$ When Britain declared in 1961 that its South-East Asian colonies would be combined to form the new state of Malaysia, Sukarno viewed this as a 'sham de-colonisation' and responded through the political and military campaign of Konfrontasi. ${ }^{17}$ Konfrontasi, however, was a military failure. As Sukarno's 'Guided Democracy' had positioned the president at the forefront of Indonesian political power, the failure of Konfrontasi was a humiliation for Sukarno.

During Konfrontasi, Sukarno implemented the seizure of foreign-owned companies operating within Indonesia. More than 90 foreign companies were taken over by the Indonesian government between September 1963 and December 1965. ${ }^{18}$ Among the companies seized were the British American Tobacco Company Limited, Caltex Oil, the Dunlop Rubber Company, the Goodyear Tire Factory, the Pan American International Oil Company, the Motion Picture Export Association of America, Shell Oil, the Singer Sewing Company, Unilever, and the Union Carbide Corporation. ${ }^{19}$ In addition to the takeover of these companies, from May 1965, 'further foreign direct investment in Indonesia was prohibited by law. ${ }^{20}$

Sukarno's campaign to nationalise the assets of foreign companies has been interpreted as 'the result of a complex confluence of Indonesian domestic political struggle and instability, foreign relations, and domestic economic policy.' ${ }^{21}$ Sukarno's motivation has been viewed as a psychological 'quest for Indonesian prestige as a leader in the destruction of the perpetrators of Indonesia's humbling colonial experience - the imperialist states of the West. ${ }^{22}$ 
In economic terms, although key Indonesian islands provided rich natural resources, oil and rubber in particular, which were sought after by foreign companies, Indonesia was not flourishing. The seizure of foreign companies during Konfrontasi did not improve the parlous state of the Indonesian economy. By 1965 , production was substantially reduced, exports and 'imports came to a halt and hyperinflation of more than 600 percent crippled the country. ${ }^{23}$ These economic problems can be linked to Sukarno's foreign policy, and the financial costs incurred through Konfrontasi and the West Papua campaign. The nation was also affected by the occurrence of food shortages and famines during the 1950 s and 1960s, although these were denied at the time by Sukarno. ${ }^{24}$

In spite of Sukarno's political rhetoric about independence, antiimperialism and anti-colonialism, Indonesia in the 1960s was reliant on the receipt of international aid. In 1961, Indonesia received military and economic aid worth an estimated $\$ 50$ million from the United States, which included 'badly needed rice shipments'. ${ }^{25}$ However, the context of the Cold War, and the policy of non-alignment adopted by Sukarno, ensured that Indonesia would receive aid from the other key power seeking influence in Indonesia: the Soviet Union. It is estimated that Indonesia received almost $\$ 1$ billion in military aid from the Soviet Union during Indonesia's operations to gain control of West Papua. ${ }^{26}$ The Cold War milieu also saw the People's Republic of China attempting to establish close diplomatic relations with Indonesia. ${ }^{27}$ Where China was politically isolated internationally through the United States' policy of 'containment,' it sought to forge with Sukarno an alliance based on mutual anti-imperialism. ${ }^{28}$

Sukarno's non-alignment policy, as well as his diplomatic ties with China, and acceptance of aid from the Soviet Union, eventually provoked a response from the United States. In December 1963, the United States withheld economic aid from Indonesia, contributing to the nation's economic problems. ${ }^{29}$ Between 1962 and 1965, all US economic aid was gradually ceased, but the United States maintained the supply of military aid to the Indonesian army. ${ }^{30}$ The United States had considered Sukarno's Indonesia a problem since its establishment as an example of 'independent nationalism'. ${ }^{31}$ John Foster Dulles, the US Secretary of State in 1958, had 'informed the National Security Council that Indonesia was one of three major world crises, along with Algeria and the Middle East. ${ }^{32}$ Dulles identified the Communist Party - the PKI - and its apparent widespread support among the peasantry as the main problem within Indonesia. ${ }^{33}$

By the mid-1960s, both domestic and international factors meant that Indonesia was poised for crisis. Indonesia's economic situation was critical, with hyperinflation exacerbating food shortages and periodic famine. The West Papua conflict had confirmed Sukarno as a leader hostile to Western powers. Konfrontasi resulted in Sukarno's leadership being viewed internationally as 
erratic and unpredictable. Tensions and antagonism between the Indonesian army and the PKI remained unresolved. Sukarno's non-alignment policy was not entirely successful in balancing the influence of the United States and the Soviet Union, and had significant repercussions with the withdrawal of US economic aid. Each of these factors contributed to the crisis that came in the form of the coup and subsequent mass killings.

The Alleged 'Failed Coup Attempt' and the Killing of the Six Indonesian Generals: Suharto seizes Power in the Indonesian Coup of 1965

The political transformation of Indonesia, which began in 1965, was initiated by an event that today is still contested by different authors. Six senior Indonesian army generals who were members of the Indonesian Army High Command were killed on the 30th September 1965. ${ }^{34}$ It was claimed that the generals were murdered by 'left-wing elements' within the army in a failed putsch devised by the Indonesian Communist Party, the PKI. ${ }^{35}$ However, some contend that PKI involvement in that event was unlikely. ${ }^{36}$ It is generally agreed that the exact details of the killing of the generals are undocumented, unknown and unverifiable. ${ }^{37}$ Nonetheless, the consequences of that event would ultimately include the ousting of Sukarno and the Indonesian mass killings. The immediate aftermath of the killing of the six generals was the rise to prominence of General Suharto, who launched a so-called 'countercoup' against the alleged killers of the generals within the army and the PKI. ${ }^{38}$ Regardless of whether the 30th September event was actually a failed attempt at a putsch, General Suharto's response represented a 'creeping coup d'état', which saw him installed as president on 12 March $1967 .{ }^{39}$

Some analysts have contended that the killing of the generals was not a PKI plot, but an 'internal army affair' that arose from 'serious tensions between officers' within different divisions of the army. ${ }^{40}$ It is argued that the generals' murder provided right-wing army members, including General Suharto, with the opportunity to purge their centrist rivals loyal to Sukarno, "paving the way to a long-planned elimination of the civilian left, and eventually to the establishment of a military dictatorship. ${ }^{41}$ Others have asserted that Suharto was the 'mastermind' of the killing of the six generals and that this was done to provide a justification for him to seize power, but this is also disputed. ${ }^{42}$

While accounts of the killing of the generals remain contentious, what is certain is the response from General Suharto to that incident. Suharto was installed as the leader of the Command for Restoration of Security and Order and, through this new role, 'he established the power of his own clique over the entire armed forces. ${ }^{\text {'4 }}$ One of Suharto's first acts was to take control of the national radio station and to shut down all newspapers, apart from two military-run newspapers. ${ }^{44}$ As a precursor to the eventual seizure of power by General Suharto, President Sukarno's speeches were no longer broadcast 
on radio nor 'accurately or fully reported in the newspapers' once Suharto had taken control of the national media. ${ }^{45}$

With President Sukarno silenced, General Suharto used his control over the media to launch a propaganda campaign about the killing of the six generals. The generals had been kidnapped, killed and their bodies were thrown down a deep well. ${ }^{46}$ However, Suharto and the army broadcast misinformation which greatly distorted and exaggerated the event. It was falsely claimed that members of a communist women's organisation, associated with the PKI, were responsible for mutilating the genitals of the six generals, gouging out their eyes, and that these women engaged in 'naked, sexual dancing' in a celebration of these macabre events. ${ }^{47}$ It was reported that the women had tortured and 'slit the bodies of the army officers with a hundred razor blades'. ${ }^{48}$ The autopsy report, signed by Suharto, indicated that the six generals had suffered none of the injuries attributed to the communist women, but the report was not released to the public, and the anti-communist propaganda campaign continued. ${ }^{49}$

The army 'made near daily announcements' about new revelations of PKI plans, such as lists of politicians and religious leaders the PKI intended to murder. ${ }^{50}$ It was claimed that PKI members had, in preparation for the execution of these hit lists, 'dug thousands of ditches around the country to hold countless corpses' ${ }^{51}$ Some of the propaganda claims were bordering on the farcical, such as the discovery of "containers filled with firearms upon which had been carved Chinese characters and slogans such as 'Long Live PKI!" 52 Nonetheless, Suharto's propaganda 'terror campaign' was highly successful in making the Indonesian 'public hate the PKI but also to feel directly threatened by it. ${ }^{\prime}$

General Suharto drew upon Cold War narratives to inform the anticommunist propaganda campaign he waged against the Indonesian Communist Party after the killing of the six generals. However, the misinformation issued by Suharto was peculiarly Indonesian, which can be understood as a 'localisation' of Cold War narratives. Suharto's propaganda played upon existing tensions within Indonesian society, such as the hostility of Muslim religious leaders and religious organisations toward the apparently atheistic PKI membership. The propaganda regarding the alleged supply of Chinese weaponry to the PKI could be interpreted as appealing to the fears of those conservatives and right-wing elements in Indonesian society disturbed by President Sukarno's friendly relations with the Soviet Union and the People's Republic of China. ${ }^{54}$ The sexual slander of communist women through the lies told about the killing of the Generals has been linked to Indonesia's sexual politics and fears about the morality and sexual freedom of communist women. It has been argued that women had some freedom and equality under Sukarno, but that the campaign of slander against communist women ensured that the submissive role of women within Indonesian society would be reinforced under Suharto. ${ }^{55}$ Moreover, it has been asserted that the mass killings would not have 
occurred without the fear and anxiety generated by Suharto's falsehoods about the gruesome torture and mutilation of the murdered generals. ${ }^{56}$

\section{The Mass Killings are Instigated and Sukarno is Ousted}

General Suharto's propaganda campaign, which followed the killing of the six army generals on the 30th September 1965, resulted in the mass murder of an unknown number of Indonesian civilians. Members, sympathisers and associates of the PKI were summarily killed, while many others were imprisoned. Some estimates suggest that between 300,000 and 500,000 Indonesians were killed due to their association with the PKI, or as a consequence of 'local disputes which could now be settled with impunity. ${ }^{57}$ Other accounts put the death toll much higher, suggesting from 500,000 up to two million Indonesians were killed. ${ }^{58}$ An estimated 500,000 to 750,000 people were imprisoned without trial for their alleged communist affiliation. ${ }^{59}$ In addition to the mass killings and imprisonment of its members, the PKI was formally banned as a political party once President Sukarno was removed from power. ${ }^{60}$

Official accounts of the massacre asserted that 'civilians who had been previously maligned or harmed by the PKI took their revenge' and that the Indonesian Army had no role in the mass killings. ${ }^{61}$ The perception persists that the mass killings were carried out 'by frenzied mobs rampaging through villages and urban neighborhoods. ${ }^{\prime 2}$ The massacre has been attributed to 'horizontal, spontaneous violence' and the depiction of Indonesians as a 'volatile, primitive people prone to violence'. ${ }^{63}$ In reality, the Indonesian army was at the centre of the mass killings, through the army's role in both the instigation and the organisation of the killings, but it is important to note that this was not simply a case of the military carrying out a slaughter of alleged communists. Many of the killings are believed to have been carried out by civilians working in conjunction with the Indonesian army.

It has been suggested that, rather than being spontaneous, the majority of the mass killings that occurred could be characterised as the "executions of detainees' ${ }^{64}$ Civilian 'murder bands' involved in the massacre were 'recruited and trained by the army on the spot', or were members of organisations loyal to the army, including some trade unions and student organisations. ${ }^{65}$ From the membership of these existing groups, 'anti-Communist mass organizations' were created, and the army 'mobilized non-communist youth groups all over Indonesia to carry out the violence' ${ }^{66}$ The mass killings were concentrated in regions of Indonesia associated with the greatest numerical support for the PKI: in the plantations of Northern Sumatra, and 'the rural areas of Central and East Java and Bali'. ${ }^{67}$

Varied explanations have been proffered to explain the involvement of civilians in the mass killings. A 'growing public mood of high tension' had 
been observed in late 1965 Indonesia. ${ }^{68}$ The PKI's increasing influence upon Indonesian politics in the early 1960s had caused opposition from nationalist and religious groups. During this period, the PKI was involved in efforts to achieve land reform and led campaigns where 'poor peasants occupied the land of their better-off neighbours' ${ }^{69}$ Some Muslim and nationalist organisations responded within Indonesia's rural areas by organising mobilisations against the PKI. ${ }^{70}$ As early as 1962, the youth faction of Indonesia's largest Muslim organisation, the Nahdlatul Ulama, had formed an armed group with the intention of preparing to challenge the PKI. ${ }^{71}$ Civilians may have participated in the massacre of those affiliated with the PKI as a result of the persuasiveness of the Indonesian army's 'key propaganda themes of Communist treachery, brutality and conspiracy'. ${ }^{72}$ While some civilian participants are said to have had religious motivations, ${ }^{73}$ others took part in the killings as a means of scoresettling in retribution for the PKI's land reform campaigns. ${ }^{74}$ Robert Cribb and Charles A. Cappel's analysis revealed that the mass killings varied greatly in different provinces, where, in some areas, 'the purge seemed to be an excuse to seize the property of party activists', while elsewhere there appeared to be 'local civil wars between or within villages'. ${ }^{75}$

The mass killings occurred over a period of months in specific regions of Indonesia, beginning in October 1965 and continuing into March 1966. ${ }^{76}$ The events were described by the CIA as 'one of the worst mass murders of the twentieth century'. ${ }^{77}$ Despite the turmoil created by the mass killings, President Sukarno's ousting was not an abrupt outcome; instead there was a gradual encroachment upon his powers as the leader of the nation. Sukarno's slow demise as president was necessary, as influential civilian groups, such as Indonesia's Muslim organisations, 'had to be won to the cause' of overthrowing Sukarno and installing General Suharto in his place. ${ }^{78}$ The granting of 'sweeping emergency powers' to General Suharto on the 11th March 1966 was a key turning point, but even this did not signal the immediate end of Sukarno's presidency. ${ }^{79}$ It was not until a full year later, on 12th March 1967, that Suharto formally assumed the role of president. ${ }^{80}$

\section{The PKI: A Powerful Political Party before the Massacre?}

With more than half a million communists killed in the massacre as a result of claims about the PKI's intentions to seize control of the nation, it is vital to examine the Indonesian Communist Party more closely in order to ascertain the PKI's position and influence within Indonesian politics in 1965. Some accounts of the PKI emphasise the size of its membership, being in the mid-1960s "the largest communist party outside the "Communist Bloc," recruited from the world's fifth largest population'. ${ }^{81}$ It is estimated that the PKI's membership in 1963 comprised 3 million Indonesians, while 17 million Indonesians were members of organisations associated with the PKI ${ }^{82}$ 
However, the size of the PKI's membership and its related organisations did not necessarily translate to the level of the party's influence within the national political arena.

In the first half of the twentieth century, the PKI had experienced periods of major turmoil in which their campaigns had failed and the party was virtually destroyed, particularly in 1926 and $1948 .{ }^{83}$ The party began to be rebuilt under the new leadership of Aidit from January 1951, but in that era 'a strategy of armed agrarian revolution was ruled out by Party weakness and division, its lack of extensive ties with the peasantry, and the nature of rural schisms. ${ }^{84}$ For the United States Secretary of State, John Foster Dulles, one of the concerns about the PKI in the late 1950s was the fact that it was achieving 'widespread support not as a revolutionary party but as an organization defending the interests of the poor within the existing system' ${ }^{85}$

While Dulles and other American Cold War advisors generally interpreted the PKI's position within the Indonesian political system as a tangible threat, the PKI's involvement in the formal political system actually represented an insurmountable constraint that reinforced the party's limitations. The PKI was subjected to frequent harassment from the Indonesian army, with the officer corps especially opposed to the continued existence of the party and its participation in national politics. ${ }^{86}$ As a result of the ongoing antagonism and hostility of the army, the PKI was reliant on President Sukarno for protection. ${ }^{87}$ The PKI's dependence on Sukarno, however, had consequences for the political ideology of the party. In particular, the PKI "was obliged to moderate its class appeals and underwrite the "revolutionary" legitimacy and power claims of the Sukarnoists. ${ }^{88}$

Although the PKI had expanded its membership and associations substantially from 1951 until it was targeted in the massacre of 1965, the PKI was never in a position to assume control of Indonesia, either through its national politics or an unlikely revolutionary struggle. The PKI was politically isolated and its participation in the political system during the Guided Democracy period was contingent upon Sukarno's approval and protection. As 'a formidable but unarmed force in Indonesian politics', the PKI was incapable of challenging the power of the army, which had been dispersed and strengthened at the local and regional level under Guided Democracy. ${ }^{89}$ The PKI polarised Indonesia's other political parties, and elements of Indonesian society were extremely hostile to the communist party. Sukarno's support for the PKI has also been exaggerated and misinterpreted. His advocacy of the PKI presented Sukarno with the opportunity and 'means of reducing the power of the strongest force' - the Indonesian army. ${ }^{90}$

The Massacre as an Unhealed Cold War Trauma within Indonesian Society 
It has been argued that the training and arming of civilians to partake in the mass killings was strategic, as 'it ensured that there would never be any investigation of the killings, since blood was on too many civilian hands. ${ }^{91}$ The horror of the killings, which saw Indonesian rivers 'bloated with corpses' and the nation 'littered' with mass graves, has never been confronted, either by any subsequent Indonesian government or within Indonesian society more generally. ${ }^{92}$ Unlike Chile, Rwanda and South Africa, the massacre that occurred in Indonesia has never been formally investigated nor has there been any kind of 'truth and reconciliation' process instituted. ${ }^{93}$ No one involved in the mass killings has been arrested or imprisoned, and an official silence on the incident has been maintained.

The mass killings remain an extremely sensitive issue in Indonesia. In 2007, when Indonesian schools received new books containing an account of the massacre which deviated from the army's official version of events, protests ensued and the books 'were collected and burnt.' 94 There reportedly continues to be a political suppression of information on the events of 1965, with the police in May 2016 preventing the screening in Yogyakarta of a documentary about those who were imprisoned in $1965 .{ }^{95}$ In May 2016, bookshops and publishing companies in Indonesia were raided by the police and books on the mass killings of 1965 were seized, while some stores have voluntarily withdrawn the books following police inspections. ${ }^{96}$ Decades after the coup and the mass killings, the official ban on the PKI has been preserved and the trauma of those events 'is still playing an important role in the national imagination. ${ }^{97}$

\section{Conclusion}

In 1948, George Kennan, the diplomat who devised the United States policy of "containment', had 'warned that a "communist" Indonesia would be an "infection" that "would sweep westward" through all of South Asia.' 98 Kennan's Cold War rhetoric was substantially different to that which would be issued by General Suharto to instigate the mass killings of alleged communists in 1965. While Suharto's propaganda drew implicitly upon Cold War narratives, it could be seen as a localised form of Cold War misinformation. The lurid and gruesome falsehoods regarding the killing of the six generals by sexually depraved communist women played upon the fears and anxieties of Indonesians, and religious groups in particular. This anti-communist propaganda was localised, and was reliant on existing tensions and hostility within Indonesian society. The local context in 1965 and the existing divisions between the PKI and others in Indonesian society were crucial to the occurrence of the coup and the mass killings.

This article has sought to reconceptualise these events as a localised Cold War. It must be noted that it has not intended to dispute or repudiate the excellent work of scholars who have revealed the role of the United States in 
these Indonesian events. The constraints of the word count have not permitted consideration of that aspect of these incidents. In emphasising the local context, this article has attempted to contribute to a deeper understanding of this highly complex and important subject.

\section{Endnotes}

1 GOOSEN, Vincent. A Far Greater Prize Than Vietnam: U.S. Foreign Policy Towards Indonesia in the Era of Vietnam (1961-1967), Masters dissertation, University of Amsterdam, Graduate School of Humanities, Institute for History, Archaeology, and Religion Studies, June 2015, p. 15.

2 CRIBB, Robert and FORD, Michele. Indonesia as an Archipelago: Managing Islands, Managing the Seas, in CRIBB, Robert and FORD, Michele (eds.) Indonesia beyond the Water's Edge: Managing an Archipelagic State, Singapore: ISEAS Publishing, 2009, p. 3.

3 GROSS, Max L. A Muslim Archipelago: Islam and Politics in Southeast Asia, Washington, DC: National Defense Intelligence College, 2007, p. 4.

4 CRIBB, Robert and FORD, Michele, Indonesia as an Archipelago: Managing Islands, Managing the Seas in CRIBB, Robert and FORD, Michele (eds.) Indonesia beyond the Water's Edge: Managing an Archipelagic State, Singapore: ISEAS Publishing, 2009, p. 5.

5 BHAKTI, Ikrar Nusa, The Transition to Democracy in Indonesia: Some Outstanding Problems in ROLFE, Jim (ed.) The Asia-Pacific: A Region in Transition, Honolulu: Asia-Pacific Center for Security Studies, 2004, p. 198.

6 BHAKTI, Ikrar Nusa, The Transition to Democracy in Indonesia: Some Outstanding Problems in ROLFE, Jim (ed.) The Asia-Pacific: A Region in Transition, Honolulu: Asia-Pacific Center for Security Studies, 2004, p. 197.

7 BUNNELL, Frederick P. Guided Democracy Foreign Policy: 1960-1965 President Sukarno Moves from Non-Alignment to Confrontation, Indonesia, No. 2, October 1966, p. 38.

8 RANSON, David. The Berkeley Mafia and the Indonesian Massacre, Ramparts Magazine, October 1970, p. 9, accessed online: <http://la.utexas.edu/users/hcleaver/357L/357LRansom BerkeleyMafiaTable.pdf>

9 RANSON, David. The Berkeley Mafia and the Indonesian Massacre, Ramparts Magazine, October 1970, p. 9, accessed online: $<$ http://la.utexas.edu/users/hcleaver/357L/357LRansom BerkeleyMafiaTable.pdf>

10 WIBISONO, Haryo Kunto. Indonesia’s Foreign Politics 1955-1965: Between Decolonisation and Beacon Politics, International Journal of Indonesian Studies, Vol. 1, Issue 2, Autumn 2015, p. 4, accessed online: <http://artsonline.monash.edu.au/indonesian-studies-journal/ files/2015/04/Indonesia\%E2\%80\%99s-foreign-politics-1955-1965.pdf>

11 WIBISONO, Haryo Kunto. Indonesia’s Foreign Politics 1955-1965: Between Decolonisation and Beacon Politics, International Journal of Indonesian Studies, Vol. 1, Issue 2, Autumn 2015, p.3-4, accessed online: <http://artsonline.monash.edu.au/indonesian-studies-journal/ files/2015/04/Indonesia\%E2\%80\%99s-foreign-politics-1955-1965.pdf>

12 ANWAR, Dewi Fortuna. Indonesia and the Bandung Conference: Then and Now in See Seng Tan and Amitav Acharya (eds.) Bandung Revisited: The Legacy of the 1955 Asian-African 
Conference for International Order, Singapore: NUS Press, 2008, p.185.

13 PIETCH, Sam. Indonesian Independence and Australian Imperialism, Australian Marxist Review, No. 10, Winter, 2015.

14 PIETCH, Sam. Indonesian Independence and Australian Imperialism, Australian Marxist Review, No. 10, Winter, 2015.

15 PIETCH, Sam. Indonesian Independence and Australian Imperialism, Australian Marxist Review, No. 10, Winter, 2015.

16 BUNNELL, Frederick P. Guided Democracy Foreign Policy: 1960-1965 President Sukarno Moves from Non-Alignment to Confrontation, Indonesia, No. 2, October 1966, p. 37.

17 PIETCH, Sam. Indonesian Independence and Australian Imperialism, Australian Marxist Review, No. 10, Winter, 2015.

18 REDFERN, William A. Sukarno's Guided Democracy and the Takeovers of Foreign Companies in Indonesia in the 1960s, Doctor of Philosophy (History) dissertation, submitted to the University of Michigan, 2010, p. 3. <https://deepblue.lib.umich.edu/bitstream/ handle/2027.42/77846/wredfern_1.pdf?sequence=1>

19 REDFERN, William A. Sukarno's Guided Democracy and the Takeovers of Foreign Companies in Indonesia in the 1960s, Doctor of Philosophy (History) dissertation, submitted to the University of Michigan, 2010, p. 586-593. <https://deepblue.lib.umich.edu/bitstream/ handle/2027.42/77846/wredfern_1.pdf?sequence $=1>$

20 REDFERN, William A. Sukarno's Guided Democracy and the Takeovers of Foreign Companies in Indonesia in the 1960s, Doctor of Philosophy (History) dissertation, submitted to the University of Michigan, 2010, p. 3. <https://deepblue.lib.umich.edu/bitstream/ handle/2027.42/77846/wredfern_1.pdf?sequence $=1>$

21 REDFERN, William A. Sukarno's Guided Democracy and the Takeovers of Foreign Companies in Indonesia in the 1960s, Doctor of Philosophy (History) dissertation, submitted to the University of Michigan, 2010, p. 3.<https://deepblue.lib.umich.edu/bitstream/ handle/2027.42/77846/wredfern_1.pdf?sequence $=1>$

22 BUNNELL, Frederick P. Guided Democracy Foreign Policy: 1960-1965 President Sukarno Moves from Non-Alignment to Confrontation, Indonesia, No. 2, October 1966, p. 38.

23 BHAKTI, Ikrar Nusa, The Transition to Democracy in Indonesia: Some Outstanding Problems in ROLFE, Jim (ed.) The Asia-Pacific: A Region in Transition, Honolulu: AsiaPacific Center for Security Studies, 2004, p. 198.

24 VAN DER ENG, Pierre. All Lies? Famines in Sukarno's Indonesia, 1950s-1960s, Paper presented to the Asian Historical Economics Society Conference, Tokyo, 13-15 September 2012, <https://crawford.anu.edu.au/pdf/events/2012/20120916-Famine-in-Indonesia-1950s60 s.pdf $>$.

25 BUNNELL, Frederick P. Guided Democracy Foreign Policy: 1960-1965 President Sukarno Moves from Non-Alignment to Confrontation, Indonesia, No. 2, October 1966, p. 49, fn. 20.

26 BUNNELL, Frederick P. Guided Democracy Foreign Policy: 1960-1965 President Sukarno Moves from Non-Alignment to Confrontation, Indonesia, No. 2, October 1966, p. 48, fn. 19.

27 WIBISONO, Haryo Kunto. Indonesia's Foreign Politics 1955-1965: Between Decolonisation and Beacon Politics, International Journal of Indonesian Studies, Vol. 1, Issue 2, Autumn 2015, p. 11, accessed online: <http://artsonline.monash.edu.au/indonesian-studies-journal/ files/2015/04/Indonesia\%E2\%80\%99s-foreign-politics-1955-1965.pdf> 
28 BUNNELL, Frederick P. Guided Democracy Foreign Policy: 1960-1965 President Sukarno Moves from Non-Alignment to Confrontation, Indonesia, No. 2, October 1966, p. 49.

29 SCOTT, Peter Dale, The United States and the Overthrow of Sukarno, 1965-1967, Pacific Affairs, No. 58, Summer 1985, p. 239-264, accessed online: <http://wvi.antenna.nl/eng/ic/ pki/pds.html>

30 SCOTT, Peter Dale, The United States and the Overthrow of Sukarno, 1965-1967, Pacific Affairs, No. 58, Summer 1985, p. 239-264, accessed online: <http://wvi.antenna.nl/eng/ic/ pki/pds.html>

31 CHOMSKY, Noam. Indonesia, Master Card in Washington's Hand, Indonesia, No. 66, October 1998, p. 2.

32 CHOMSKY, Noam. Indonesia, Master Card in Washington's Hand, Indonesia, No. 66, October 1998, p. 2.

33 CHOMSKY, Noam. Indonesia, Master Card in Washington's Hand, Indonesia, No. 66, October 1998, p. 2.

34 GOOSEN, Vincent. A Far Greater Prize Than Vietnam: U.S. Foreign Policy Towards Indonesia in the Era of Vietnam (1961-1967), Masters dissertation, University of Amsterdam, Graduate School of Humanities, Institute for History, Archaeology, and Religion Studies, June 2015 , p. 8.

35 BHAKTI, Ikrar Nusa, The Transition to Democracy in Indonesia: Some Outstanding Problems in ROLFE, Jim (ed.) The Asia-Pacific: A Region in Transition, Honolulu: AsiaPacific Center for Security Studies, 2004, p. 198.

36 RAMSON, David. The Berkeley Mafia and the Indonesian Massacre, Ramparts Magazine, October 1970, p. 10, accessed online: <http:/la.utexas.edu/users/hcleaver/357L/357LRanso mBerkeleyMafiaTable.pdf>

37 SCOTT, Peter Dale. The United States and the Overthrow of Sukarno, 1965-1967, Pacific Affairs, No. 58, Summer 1985, p.239-264, accessed online: $<$ http://wvi.antenna.nl/eng/ic/pki/ pds.html >; PIETCH, Sam, Indonesian Independence and Australian Imperialism, Australian Marxist Review, No. 10, Winter, 2015.

38 GOOSEN, Vincent. A Far Greater Prize Than Vietnam: U.S. Foreign Policy Towards Indonesia in the Era of Vietnam (1961-1967), Masters dissertation, University of Amsterdam, Graduate School of Humanities, Institute for History, Archaeology, and Religion Studies, June 2015 , p. 8.

39 GOOSEN, Vincent. A Far Greater Prize Than Vietnam: U.S. Foreign Policy Towards Indonesia in the Era of Vietnam (1961-1967), Masters dissertation, University of Amsterdam, Graduate School of Humanities, Institute for History, Archaeology, and Religion Studies, June 2015 , p. 8.

40 RAMSON, David Ransom. The Berkeley Mafia and the Indonesian Massacre, Ramparts Magazine, October 1970, p. 10, accessed online: <http://a.utexas.edu/users/hcleaver/357L/3 57LRansomBerkeleyMafiaTable.pdf $>$

41 SCOTT, Peter Dale. The United States and the Overthrow of Sukarno, 1965-1967, Pacific Affairs, No. 58, Summer 1985, p.239-264, accessed online: <http://wvi.antenna.nl/eng/ic/ pki/pds.html>

42 FARID, Hilmar. Indonesia's original sin: mass killings and capitalist expansion, 1965-66, Inter-Asia Cultural Studies, Vol. 6, Issue 1, 2005, p.3-16, accessed online. 
43 FARID, Hilmar. Indonesia's original sin: mass killings and capitalist expansion, 1965-66, Inter-Asia Cultural Studies, Vol. 6, Issue 1, 2005, p.3-16, accessed online.

44 FARID, Hilmar. Indonesia’s original sin: mass killings and capitalist expansion, 1965-66, Inter-Asia Cultural Studies, Vol. 6, Issue 1, 2005, p.3-16, accessed online.

45 FARID, Hilmar. Indonesia's original sin: mass killings and capitalist expansion, 1965-66, Inter-Asia Cultural Studies, Vol. 6, Issue 1, 2005, p.3-16, accessed online.

46 WIERINGA, Saskia Eleonora. Sexual Slander and the 1965/66 Mass Killings in Indonesia: Political and Methodological Considerations, Journal of Contemporary Asia, Vol. 41, No. 4, p. 549.

47 WIERINGA, Saskia Eleonora. Sexual Slander and the 1965/66 Mass Killings in Indonesia: Political and Methodological Considerations, Journal of Contemporary Asia, Vol. 41, No. 4, p. 551 .

48 ROOSA, John and NEVINS, Joseph. The 1965 Mass Killings in Indonesia: CIA Blames the Victims For Being Murdered, Asia-Pacific Research, July 24 2016, accessed online:

$<$ http://www.asia-pacificresearch.com/the-1965-mass-killings-in-indonesia-cia-blames-thevictims-for-being-murdered/5537708>

49 WIERINGA, Saskia Eleonora. Sexual Slander and the 1965/66 Mass Killings in Indonesia: Political and Methodological Considerations, Journal of Contemporary Asia, Vol. 41, No. 4, p.552.

50 FARID, Hilmar. Indonesia's original sin: mass killings and capitalist expansion, 1965-66, Inter-Asia Cultural Studies, Vol. 6, Issue 1, 2005, p.3-16, accessed online.

51 ROOSA, John and NEVINS, Joseph. The 1965 Mass Killings in Indonesia: CIA Blames the Victims For Being Murdered, Asia-Pacific Research, July 24 2016, accessed online:

$<$ http://www.asia-pacificresearch.com/the-1965-mass-killings-in-indonesia-cia-blames-thevictims-for-being-murdered/5537708>

52 FARID, Hilmar. Indonesia's original sin: mass killings and capitalist expansion, 1965-66, Inter-Asia Cultural Studies, Vol. 6, Issue 1, 2005, p.3-16, accessed online.

53 FARID, Hilmar. Indonesia's original sin: mass killings and capitalist expansion, 1965-66, Inter-Asia Cultural Studies, Vol. 6, Issue 1, 2005, p.3-16, accessed online.

54 ROOSA, John and NEVINS, Joseph. The 1965 Mass Killings in Indonesia: CIA Blames the Victims For Being Murdered, Asia-Pacific Research, July 24 2016, accessed online:

$<$ http://www.asia-pacificresearch.com/the-1965-mass-killings-in-indonesia-cia-blames-thevictims-for-being-murdered/5537708>

55 WIERINGA, Saskia Eleonora. Sexual Slander and the 1965/66 Mass Killings in Indonesia: Political and Methodological Considerations, Journal of Contemporary Asia, Vol. 41, No. 4, p. 554-555.

56 WIERINGA, Saskia Eleonora. Sexual Slander and the 1965/66 Mass Killings in Indonesia: Political and Methodological Considerations, Journal of Contemporary Asia, Vol. 41, No. 4, p. 554-555.

57 PIETCH, Sam. Indonesian Independence and Australian Imperialism, Australian Marxist Review, No. 10, Winter, 2015.

58 ANDERSON, Benedict. Exit Suharto: Obituary for a Mediocre Tyrant, New Left Review, 
50, March-April 2008.

59 ANDERSON, Benedict. Exit Suharto: Obituary for a Mediocre Tyrant, New Left Review, 50, March-April 2008; GOOSEN, Vincent. A Far Greater Prize Than Vietnam: U.S. Foreign Policy Towards Indonesia in the Era of Vietnam (1961-1967), Masters dissertation, University of Amsterdam, Graduate School of Humanities, Institute for History, Archaeology, and Religion Studies, June 2015, p. 8.

60 WIBISONO, Haryo Kunto. Indonesia's Foreign Politics 1955-1965: Between Decolonisation and Beacon Politics, International Journal of Indonesian Studies, Vol. 1, Issue 2, Autumn 2015, p. 13, accessed online: <http://artsonline.monash.edu.au/indonesian-studies-journal/ files/2015/04/Indonesia\%E2\%80\%99s-foreign-politics-1955-1965.pdf>

61 FARID, Hilmar. Indonesia's original sin: mass killings and capitalist expansion, 1965-66, Inter-Asia Cultural Studies, Vol. 6, Issue 1, 2005, p.3-16, accessed online.

62 ROOSA, John and NEVINS, Joseph. The 1965 Mass Killings in Indonesia: CIA Blames the Victims For Being Murdered, Asia-Pacific Research, July 24 2016, accessed online:

$<$ http://www.asia-pacificresearch.com/the-1965-mass-killings-in-indonesia-cia-blames-thevictims-for-being-murdered/5537708>

63 FARID, Hilmar. Indonesia's original sin: mass killings and capitalist expansion, 1965-66, Inter-Asia Cultural Studies, Vol. 6, Issue 1, 2005, p.3-16, accessed online.

64 ROOSA, John and NEVINS, Joseph. The 1965 Mass Killings in Indonesia: CIA Blames the Victims For Being Murdered, Asia-Pacific Research, July 24 2016, accessed online:

$<$ http://www.asia-pacificresearch.com/the-1965-mass-killings-in-indonesia-cia-blames-thevictims-for-being-murdered/5537708>

65 SCOTT, Peter Dale. The United States and the Overthrow of Sukarno, 1965-1967, Pacific Affairs, No. 58, Summer 1985, p.239-264, accessed online: <http://wvi.antenna.nl/eng/ic/ pki/pds.html>

66 FARID, Hilmar. Indonesia's original sin: mass killings and capitalist expansion, 1965-66, Inter-Asia Cultural Studies, Vol. 6, Issue 1, 2005, p.3-16, accessed online.

67 ANDERSON, Benedict. Exit Suharto: Obituary for a Mediocre Tyrant, New Left Review, 50, March-April 2008.

68 FEIN, Helen. Revolutionary and Antirevolutionary Genocides: A Comparison of State Murders in Democratic Kampuchea, 1975 to 1979, and in Indonesia, 1965 to 1966, Comparative Studies in Society and History, 1993, Vol. 35, No. 4, p.799.

69 CROUCH, Harold. Patrimonialism and Military Rule in Indonesia, World Politics, 1979, Vol. 31, No. 4, p.574.

70 CROUCH, Harold. Patrimonialism and Military Rule in Indonesia, World Politics, 1979, Vol. 31, No. 4, p.574.

71 MCGREGOR, Katharine E. Confronting the Past in Contemporary Indonesia: The Anticommunist Killings of 1965-66 and the Role of the Nahdlatul Ulama, Critical Asian Studies, Vol. 41, No. 2, 2009, p. 198.

72 HENRY, Adam Hughes. Polluting the Waters, Genocide Studies International, Vol. 8, No. 2, 2014, p.153.

73 MCGREGOR, Katharine E. Confronting the Past in Contemporary Indonesia: The Anticommunist Killings of 1965-66 and the Role of the Nahdlatul Ulama, Critical Asian 
Studies, Vol. 41, No. 2, 2009, p. 196.

74 GITTINGS, John. The Indonesian Massacres, 1965-66: Image and Reality in LEVENE, Mark and ROBERTS, Penny (eds.), The Massacre in History, New York: Berghahn Books, 1999, p.247-262. Accessed online: http://www.johngittings.com/id58.html

75 CRIBB, Robert and COPPEL, Charles A. A genocide that never was: explaining the myth of anti-Chinese massacres in Indonesia, 1965-66, Journal of Genocide Research, Vol. 11, No. 4, 2009, p.449.

76 ANDERSON, Benedict. Exit Suharto: Obituary for a Mediocre Tyrant, New Left Review, 50, March-April 2008; MANNE, Robert and AARONS, Mark. Rivers Ran Red: Indonesia's mass killings have been overlooked for 50 years, The Monthly, March 2016, p.20.

77 PIETCH, Sam. Indonesian Independence and Australian Imperialism, Australian Marxist Review, No. 10, Winter, 2015.

78 DRAKELEY, Steven. Indonesia's Muslim Organisations and the Overthrow of Sukarno, Studia Islamika: Indonesian Journal for Islamic Studies, Vol. 21, No. 2, 2014, p. 225.

79 DRAKELEY, Steven. Indonesia's Muslim Organisations and the Overthrow of Sukarno, Studia Islamika: Indonesian Journal for Islamic Studies, Vol. 21, No. 2, 2014, p. 199-200.

80 GOOSEN, Vincent. A Far Greater Prize Than Vietnam: U.S. Foreign Policy Towards Indonesia in the Era of Vietnam (1961-1967), Masters dissertation, University of Amsterdam, Graduate School of Humanities, Institute for History, Archaeology, and Religion Studies, June 2015, p. 8 .

81 GOOSEN, Vincent. A Far Greater Prize Than Vietnam: U.S. Foreign Policy Towards Indonesia in the Era of Vietnam (1961-1967), Masters dissertation, University of Amsterdam, Graduate School of Humanities, Institute for History, Archaeology, and Religion Studies, June 2015, p. 8 .

82 RAMSON, David. The Berkeley Mafia and the Indonesian Massacre, Ramparts Magazine, October 1970, p. 9, accessed online: <http://la.utexas.edu/users/hcleaver/357L/357LRansom BerkeleyMafiaTable.pdf $>$

83 MORTIMER, Rex. Class, Social Cleavage and Indonesian Communism, Indonesia, No. 8, October 1969, p.6-7.

84 MORTIMER, Rex. Class, Social Cleavage and Indonesian Communism, Indonesia, No. 8, October 1969, p.7-8.

85 CHOMSKY, Noam. Indonesia, Master Card in Washington's Hand, Indonesia, No. 66, October 1998, p.2.

86 BUNNELL, Frederick P. Guided Democracy Foreign Policy: 1960-1965 President Sukarno Moves from Non-Alignment to Confrontation, Indonesia, No. 2, October 1966, p. 41.

87 BUNNELL, Frederick P. Guided Democracy Foreign Policy: 1960-1965 President Sukarno Moves from Non-Alignment to Confrontation, Indonesia, No. 2, October 1966, p. 44.

88 MORTIMER, Rex. Class, Social Cleavage and Indonesian Communism, Indonesia, No. 8, October 1969, p.11.

89 GOOSEN, Vincent. A Far Greater Prize Than Vietnam: U.S. Foreign Policy Towards Indonesia in the Era of Vietnam (1961-1967), Masters dissertation, University of Amsterdam, Graduate School of Humanities, Institute for History, Archaeology, and Religion Studies, June 2015, p. 8. 
90 BUNNELL, Frederick P. Guided Democracy Foreign Policy: 1960-1965 President Sukarno Moves from Non-Alignment to Confrontation, Indonesia, No. 2, October 1966, p. 41.

91 ANDERSON, Benedict. Exit Suharto: Obituary for a Mediocre Tyrant, New Left Review, 50, March-April 2008.

92 MANNE, Robert and AARONS, Mark. Rivers Ran Red: Indonesia's mass killings have been overlooked for 50 years, The Monthly, March 2016, p.20.

93 WIERINGA, Saskia Eleonora. Sexual Slander and the 1965/66 Mass Killings in Indonesia: Political and Methodological Considerations, Journal of Contemporary Asia, Vol. 41, No. 4, p.545.

94 WIERINGA, Saskia Eleonora. Sexual Slander and the 1965/66 Mass Killings in Indonesia: Political and Methodological Considerations, Journal of Contemporary Asia, Vol. 41, No. 4, p.547.

95 BALOWSKI, James. The shifting terrain of Indonesian politics, Red Flag, Issue 75, 4 July 2016, p.20.

96 BALOWSKI, James. The shifting terrain of Indonesian politics, Red Flag, Issue 75, 4 July 2016, p.20.

97 WIERINGA, Saskia Eleonora. Sexual Slander and the 1965/66 Mass Killings in Indonesia: Political and Methodological Considerations, Journal of Contemporary Asia, Vol. 41, No. 4, p. 545.

98 CHOMSKY, Noam. 'Indonesia, Master Card in Washington's Hand,' Indonesia, No. 66, October 1998, p.2.

Artigo recebido em setembro de 2016. Aceito em outubro de 2016. 